\title{
Sperm DNA fragmentation induced by DNAse I and hydrogen peroxide: an in vitro comparative study among different mammalian species
}

\author{
Paola Villani, Patrizia Eleuteri, Maria Giuseppa Grollino, Michele Rescia, Pierluigi Altavista, \\ Marcello Spanò, Francesca Pacchierotti and Eugenia Cordelli
}

Unit of Radiation Biology and Human Health, Laboratory of Toxicology, ENEA CR Casaccia, Via Anguillarese 301, 00123 Rome, Italy

Correspondence should be addressed to E Cordelli; Email: eugenia.cordelli@enea.it

\begin{abstract}
Sperm DNA damage may have adverse effects on reproductive outcome. Sperm DNA breaks can be detected by several tests, which evaluate DNA integrity from different and complementary perspectives and offer a new class of biomarkers of the male reproductive function and of its possible impairment after environmental exposure. The remodeling of sperm chromatin produces an extremely condensed nuclear structure protecting the nuclear genome from adverse environments. This nuclear remodeling is species specific, and differences in chromatin structure may lead to a dissimilar DNA susceptibility to mutagens among species. In this study, the capacity of the comet assay in its two variants (alkaline and neutral) to detect DNA/chromatin integrity has been evaluated in human, mouse, and bull sperm. The hypothesis that chromatin packaging might influence the amount of induced and detectable DNA damage was tested by treating sperm in vitro with DNAse $\mathrm{I}$, whose activity is strictly dependent upon its DNA accessibility. Furthermore, hydrogen peroxide $\left(\mathrm{H}_{2} \mathrm{O}_{2}\right)$ was used to assess whether spermatozoa of the three species showed a different sensitivity to oxidative stress. DNAse I-induced damage was also assessed by the sperm chromatin structure assay and the TUNEL assay, and the performances of these two assays were compared and correlated with the comet assay results. Results showed a different sensitivity to DNAse I treatment among the species with human sperm resulting the most susceptible. On the contrary, no major differences among species were observed after $\mathrm{H}_{2} \mathrm{O}_{2}$ treatment. Furthermore, the three tests show a good correlation in revealing sperm with DNA strand breaks.
\end{abstract}

Reproduction (2010) 140 445-452

\section{Introduction}

Sperm DNA integrity is considered pivotal for normal fertilization and transmission of paternal genetic information. Unspecific sperm DNA breaks can be conveniently detected by a variety of in situ tests, the most common being the single cell gel electrophoresis or comet assay (Singh et al. 1989, Speit et al. 2009), the TUNEL assay (Gorczyca et al. 1993), and the sperm chromatin structure assay (SCSA; Evenson et al. 1980, 2002). Their application has shown that sperm DNA (and chromatin) damage can be associated with reduced rates of fertilization in vivo, by natural and assisted conception (Spano et al. 2000, Bungum et al. 2007). Their predictive value for spontaneous abortions, malformations, developmental defects, or chromosomal damage in offspring is under active investigation (Lewis \& Agbaje 2008, Sakkas \& Alvarez 2010). These tests have been demonstrated to be also useful in epidemiology studies aimed at investigating the reproductive impact of environmental or occupational compounds and in experimental toxicology trials to evaluate the reprotoxicity of physical-chemical noxiae (Evenson \& Wixon 2005, Rignell-Hydbom et al. 2005, Spano et al. 2005, Bennetts et al. 2008, Perry 2008, Delbès et al. 2010). In spite of the multiple applications of these tests in different fields and the efforts carried out to improve their sensitivity (Mitchell et al. 2010), further studies to fully understand their significance, sensitivity, and correlation seem necessary (Barratt et al. 2010).

The structural remodeling of sperm chromatin is species specific, and contributes to the protection of the nuclear genome of these DNA repair-deprived cells from the adverse environments to which they might be exposed before fertilization. During spermatogenesis, the chromatin of mammalian spermatozoa undergoes a dramatic reorganization, as histones are replaced by protamines. In mature sperm cells, this remodeled genomic architecture maintains the DNA in a highly compact and transcriptionally inactive state pending eventual fertilization of an oocyte (Braun 2001, Dadoune 2003, Oliva 2006). Protamines are cysteine-rich molecules 
that locate to the minor groove of the sperm DNA and become extensively cross-linked by disulfide bridges during epididymal transit in order to confer stability upon such an extremely compressed nuclear structure. There are two protamine families, protamine 1 and protamine 2, the relative proportion of which is different among species. Within a species, both the total protamine concentration and their relative proportion are related to sperm DNA fragmentation and infertility (Aoki et al. 2005a, 2005b), an observation that highlights the significance of chromatin compaction as a key factor in its vulnerability to damage. Finally, several mammalian species retain a nucleohistone component within their sperm chromatin (Corzett et al. 2002, Dadoune 2003, Wykes \& Krawetz 2003, Miller et al. 2010). The retained nucleosomes might be due to inefficient protamine replacement or, as recent research suggests, sperm histones could be associated with specific sequences important for embryo development (Zalenskaya et al. 2000, Nazarov et al. 2008, Arpanahi et al. 2009, Barroso et al. 2009, Hammoud et al. 2009, Miller et al. 2010). These differences in chromatin structure may determine differences in sperm DNA damage susceptibility to a given stressor (Bennetts \& Aitken 2005) and, in turn, can also impact on the results obtained after using a particular sperm DNA fragmentation assay (Mitchell et al. 2010).

The evaluation of chromatin integrity is important not only in human clinical and toxicological studies but also in species used in laboratory toxicological studies, such as small rodents (Traina et al. 2003, Speit et al. 2009), and to assess sperm quality in animals selected for assisted reproduction practice in zootechny (Rybar et al. 2009).

In this study, the capacity of the alkaline and neutral comet assay to detect DNA/chromatin integrity has been evaluated in human, mouse, and bull spermatozoa. The relative amount of proteins associated with sperm chromatin is different in these species, bull sperm have only protamine 1 while the proportion of protamine 2 is 67 and $34 \%$ in human and mouse spermatozoa respectively. In addition, some nucleosomal structure is retained in human (up to $15 \%$ ) and, in smaller quantity, in mouse spermatozoa (Pittoggi et al. 1999, Wykes \& Krawetz 2003). DNA lesions were induced by treating spermatozoa in vitro with two compounds with different and well-known characteristics and mechanisms of action. DNAse $\mathrm{I}$ is an endonuclease cleaving DNA phosphodiester bonds, thus inducing DNA strand breaks. The enzyme digests DNA with no sequence specificity, but its action in nuclei is dependent on the accessibility of chromatin and, for this reason, it has been used to study the organization of chromatin in somatic cells (Pan \& Lazarus 1997, Staynov 2000, 2008). The effects of the DNAse I treatment on the sperm from the three different species have also been assessed applying the SCSA and the TUNEL assay by flow cytometry (FCM). The other compound tested was hydrogen peroxide $\left(\mathrm{H}_{2} \mathrm{O}_{2}\right)$, a small molecule inducing DNA lesions through the generation of oxygen free radicals. Both the sugar and the base moieties are susceptible to oxidation, causing predominantly singlestrand breaks (SSBs) and oxidative base damage, while double-strand breaks (DSBs) are considered to be rare events (Rueff et al. 1993).

\section{Results}

The amount of DNA lesions induced by different concentrations of DNAse I has been evaluated by alkaline and neutral comet assay in human, bull, and mouse spermatozoa. Results, expressed as mean fraction of tail DNA and percentage of damaged cells, are reported in Fig. 1. Dose-response relationships obtained with alkaline and neutral comet assays were similar, suggesting a prevalence of DSBs induced by DNAse I. Dose-effect relationships were different for the three species analyzed. Human spermatozoa, which showed a higher level of baseline lesions than the other species (in alkaline comet assay mean fraction tail DNA was 0.062 in humans and 0.023 and 0.019 in bull and mouse respectively), resulted the most sensitive, exhibiting a significant increase of comet parameters from the lowest dose tested. The curve reached a plateau and no further increase in DNA migration was observed from the concentration of $2 \mathrm{U} / \mathrm{ml}$ of DNAse I onwards $(P<0.001$ for all parameters). Bull spermatozoa showed a clear dose-dependent increase in comet parameters significant from the concentration of $100 \mathrm{U} / \mathrm{ml}$ of DNAse I
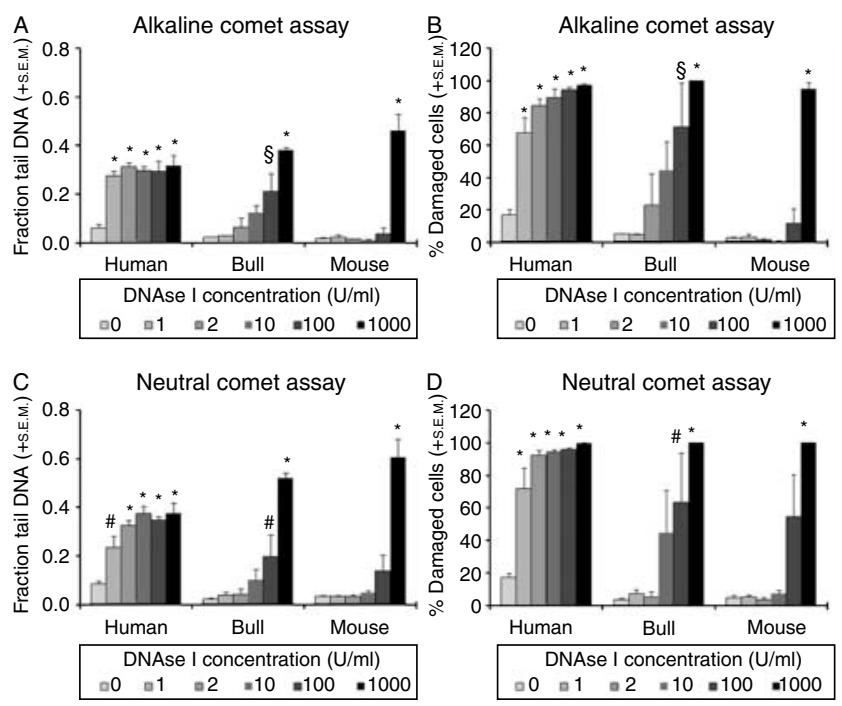

Figure 1 Effects of DNAse I treatment in human, bull, and mouse spermatozoa evaluated by alkaline (A and B) and neutral (C and D) comet assay. Columns represent the mean values of fraction of tail DNA ( $A$ and $C$ ) and the percentages of damaged cells (B and D) obtained in at least four independent experiments. Symbols show statistical difference from the relative controls $\left({ }^{\#} P \leq 0.05 ;{ }^{\circledR} P \leq 0.01 ;{ }^{*} P \leq 0.001\right)$. 
that induced DNA damage in about $60 \%$ of spermatozoa $(P=0.01$ and $P=0.027$ for alkaline and neutral comet assay respectively). Enhancing the dose, the mean level of damage increased $(P<0.001)$ and damaged cells reached $100 \%(P<0.001)$. Mouse spermatozoa were extremely resistant to the endonucleasic treatment not showing an increase in comet parameters but at the highest dose, which induced a high level of damage in $100 \%$ of spermatozoa $(P<0.001$ for all the parameter analyzed).

The outcome of DNAse I treatment on sperm DNA was also evaluated by TUNEL assay and by SCSA, and results, expressed as percentages of damaged cells, are reported in Figs 2 and 3 respectively. Also processed by these techniques, human spermatozoa resulted more sensitive to DNAse I treatment than spermatozoa from the other two species, showing a significant increase in percentage of damaged cells at all the doses tested. In mouse, only the highest concentration of DNAse I induced a significant increase in damaged spermatozoa. As for comet assay at $1000 \mathrm{U} / \mathrm{ml}$, TUNEL assay revealed that almost all cells were damaged $(P<0.001)$, while only $9 \%$ of cells were positive analyzed by SCSA $(P=0.011)$.

Percentages of damaged cells observed with the different techniques were compared and are reported in Fig. 4. A significant correlation was observed between the four methods as shown by the high values of Pearson's correlation coefficients $(R)$. The slope of the linear regressions suggests a similar sensitivity of the methods in detecting damaged cells; only in mouse, comparing SCSA with the other techniques, the slope of regression lines indicated that only a fraction of damaged sperm could be revealed by this method.

Alkaline and neutral comet assays were used to assess DNA damage induced by different concentrations of $\mathrm{H}_{2} \mathrm{O}_{2}$, and data obtained are reported in Fig. 5. As shown

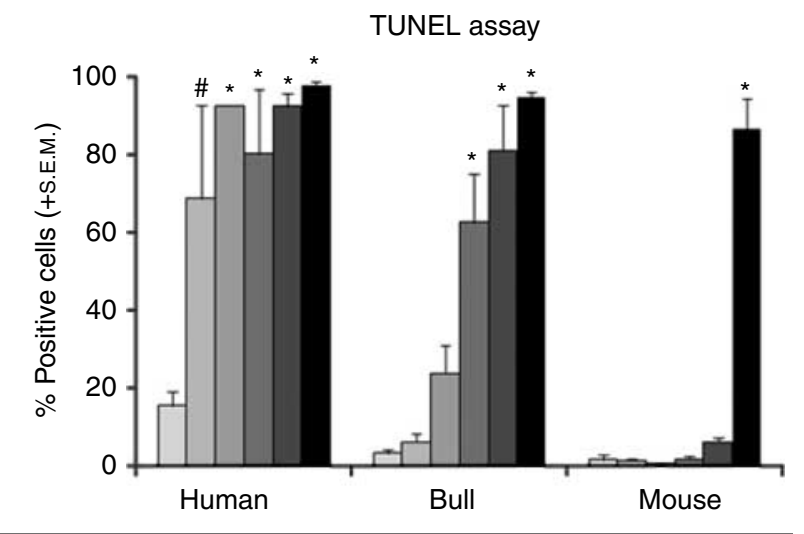

DNAse I concentration $(\mathrm{U} / \mathrm{ml}) \square 0 \quad \square 1 \quad \square 2 \square 10 \square 100 \square 1000$

Figure 2 Effects of DNAse I treatment in human, bull, and mouse spermatozoa evaluated by TUNEL assay. Columns represent the percentages of positive cells obtained in at least four independent experiments. Symbols show statistical difference from the relative controls $\left({ }^{\#} P \leq 0.05 ;{ }^{*} P \leq 0.001\right)$.

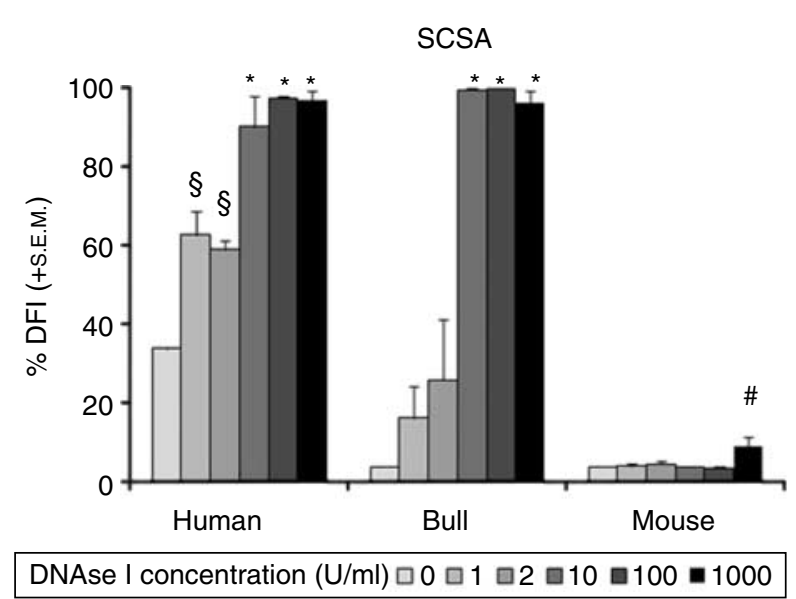

Figure 3 Effects of DNAse I treatment in human, bull, and mouse spermatozoa evaluated by SCSA. Columns represent the percentages of DFI obtained in at least four independent experiments. Symbols show statistical difference from the relative controls $\left({ }^{\sharp} P \leq 0.05 ;{ }^{\S} P \leq 0.01\right.$; $* P \leq 0.001)$.

by the histograms, differently from DNAse I treatment, the amount of DNA lesions induced by $\mathrm{H}_{2} \mathrm{O}_{2}$ was similar in the different species. The alkaline comet assay gave a dose-dependent increase in the mean values of fraction tail DNA, while this parameter was not enhanced using the neutral protocol, reinforcing the notion that $\mathrm{H}_{2} \mathrm{O}_{2}$ prevalently induces DNA SSBs.

\section{Discussion}

The tightly packaged structure of chromatin confers to mammalian sperm a protection from the effect of genotoxic factors. Nevertheless, in humans, a fraction of spermatozoa has a relative high degree of DNA fragmentation. This damage can derive from aberrant chromatin packaging during spermatogenesis, defective apoptosis, or excessive production of reactive oxygen species in the ejaculate. Furthermore, DNA damage can be induced by environmental exposure to genotoxic agents whose efficiency depends also on the accessibility of DNA (Bennetts \& Aitken 2005, Chohan et al. 2006, Perry 2008, Sakkas \& Alvarez 2010). The proposed mechanisms are obviously not mutually exclusive and, recently, a two-step hypothesis has been put forward where faulty spermatogenesis can easily lead to defective chromatin remodeling where regions of underprotaminated DNA are more susceptible and vulnerable to a variety of stressors (Aitken et al. 2009, Aitken \& De luliis 2010).

Recently, DNAse I digestion was used to characterize the sequences associated with nucleosomal structures in sperm chromatin, exploiting its ability to preferentially attack chromatin that is in an open conformation (Arpanahi et al. 2009). In our paper, the hypothesis that chromatin packaging might influence the amount of induced DNA damage was tested by treating sperm 

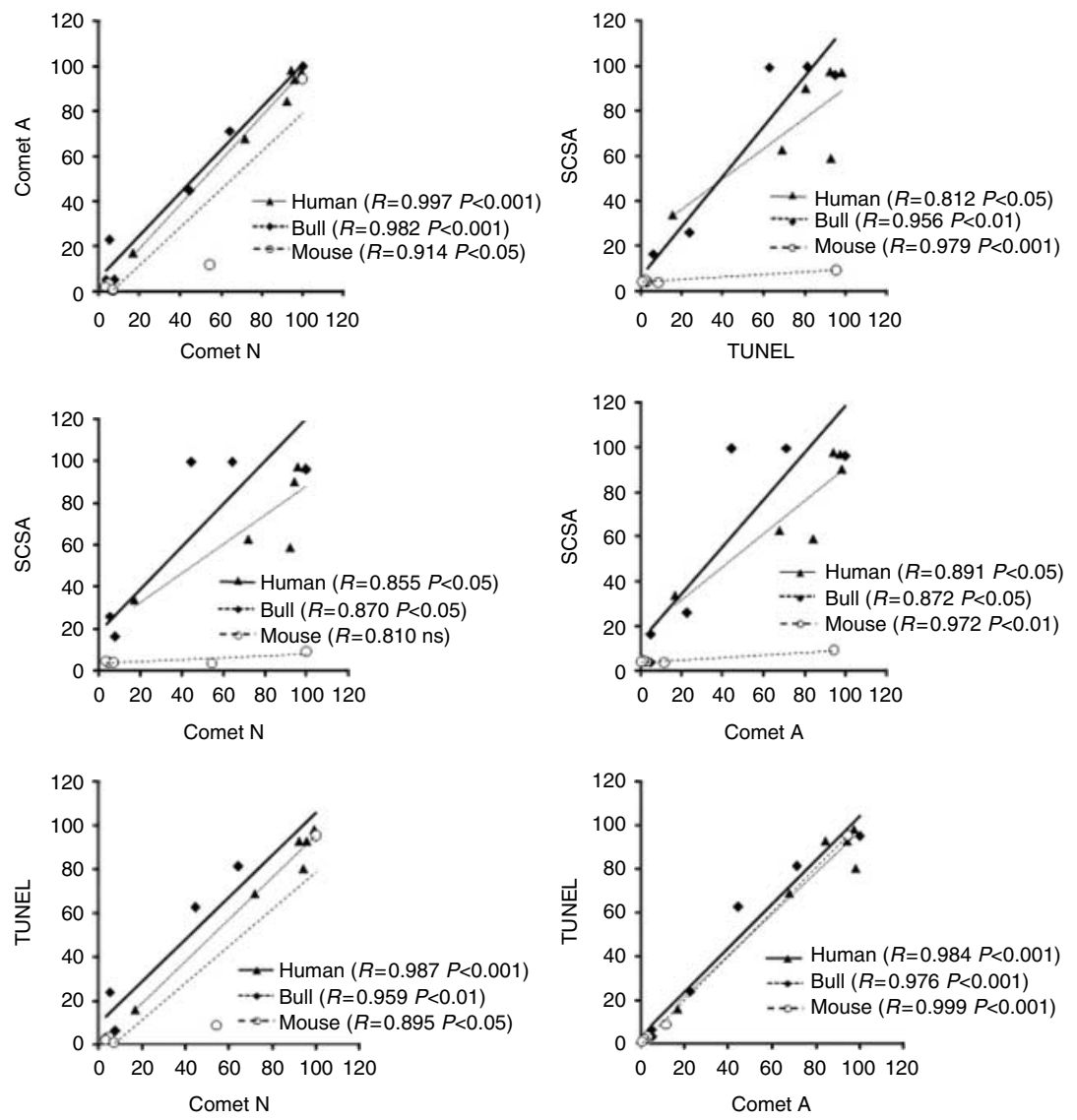

Figure 4 Relationships between the percentages of sperm with damaged DNA obtained with the different assays in human, bull, and mouse spermatozoa. in vitro with DNAse I. Our results with comet assay showed that although in all species at the highest dose tested all sperm were damaged, the amount of migrated DNA did not exceed $60 \%$. This finding could be in accordance with a model for sperm chromatin structure, in which DNA is organized with protamines into toroids connected by more relaxed toroid linker regions. These regions could be more accessible to DNAse I. At higher concentrations, DNAse I cleaves also the chromatin fibers that are on the surface of the protamine toroid while the chromatin fibers inside the toroid are completely covered by neighboring protamine-DNA strands and are totally inaccessible to any exogenous protein (Sotolongo et al. 2003, 2005, Ward 2010). This could explain that not all the DNA is digested by the enzyme, and not all the DNA can exit from the nucleoid during electrophoresis. Furthermore, results revealed a different sensitivity among the three species tested, with human spermatozoa being the most sensitive to DNAse I treatment suggesting that the bulky molecule of DNAse I could better reach and digest the human sperm DNA. In sperm, the ratio between histones and protamines differs among species, and the characteristics of the protamines also vary from species to species (Wykes \& Krawetz 2003, Miller et al. 2010, Ward 2010). It has been demonstrated that histone-bound DNA of somatic cells is much more sensitive to DNAse I than protamine-bound chromatin (Sotolongo et al. 2003, Arpanahi et al. 2009). Taking into account that in human sperm, about $15 \%$ of the DNA remains associated with histones as compared with $\sim 1 \%$ in mouse and bull, which show a similar total protamine mass to DNA mass ratio (Palmer et al. 1991, Bench et al. 1996, Miller et al. 2010), this could explain the higher sensitivity of this species with respect to the others.

It has been proposed that oxidative stress constitutes one of the mechanisms for creation of DNA damage in sperm, and that in humans, defective chromatine remodeling renders sperm particularly susceptible to oxidative attack (Aitken \& De luliis 2010). To investigate whether sperm with dissimilar histone to protamine ratio had a different sensitivity, in this study, alkaline and neutral comet assays were applied to detect DNA lesions induced by $\mathrm{H}_{2} \mathrm{O}_{2}$ in human, bull and mouse spermatozoa. No major differences among species were observed after $\mathrm{H}_{2} \mathrm{O}_{2}$ treatment indicating that the differences in chromatin compactness do not impact on the capacity of this small molecule to reach and interact with DNA. A previous study (Bennetts \& Aitken 2005) found a marked vulnerability to oxidative stress in marsupial spermatozoa, attributable to the extremely relaxed chromatin due to the lack of disulfide cross-linking in 

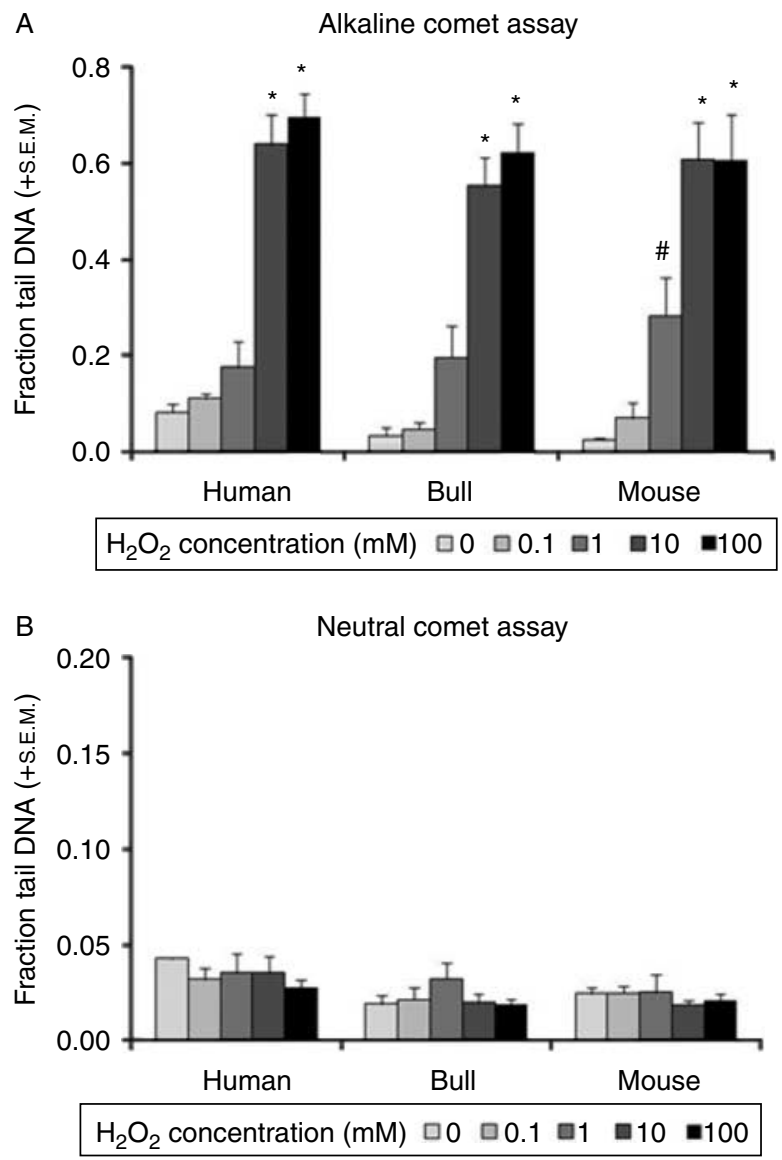

Figure 5 Effects of $\mathrm{H}_{2} \mathrm{O}_{2}$ treatment in human, bull, and mouse spermatozoa evaluated by alkaline $(\mathrm{A})$ and neutral $(\mathrm{B})$ comet assay. Columns represent the mean values of fraction of tail DNA obtained in at least four independent experiments. Symbols show statistical difference from the relative controls $\left({ }^{\sharp} P \leq 0.05 ;{ }^{*} P \leq 0.001\right)$.

their sperm chromatin with respect to sperm of eutherian species. They also found a slight higher sensitivity to $\mathrm{H}_{2} \mathrm{O}_{2}$ of human than mouse spermatozoa. The discrepancies between these and our results could be attributable to the different techniques used and to the different range of concentrations used.

Our results show that only the alkaline electrophoretic conditions could detect $\mathrm{H}_{2} \mathrm{O}_{2}$-induced DNA damage. Recently, some controversies arose regarding the kind of DNA breaks the neutral and alkaline version of comet assay could detect (Collins et al. 2008, Speit et al. 2009). Since $\mathrm{H}_{2} \mathrm{O}_{2}$-induced DSBs are negligible with respect to SSB, our results showing no DNA migration under neutral electrophoretic conditions even after extremely high concentrations, adding further evidence to the hypothesis that SSBs are not detected under nondenaturing conditions. Our alkaline comet assay, conducted under $\mathrm{pH} 12.1$ unwinding and electrophoretic conditions, showed a lower sensitivity than that reported by other authors at $\mathrm{pH} \geq 13$ (Hughes et al. 1996, Bennetts et al. 2008) reflecting the contribution of
$\mathrm{H}_{2} \mathrm{O}_{2}$-induced oxidized bases, which could be revealed as alkaline labile sites only at $\mathrm{pH} \geq 13$.

In the present work, further to neutral and alkaline comet assay, we applied TUNEL assay and SCSA to detect DNAse I-induced DNA lesions. Comet assay detects DNA strand breaks exploiting the electrophoretic mobilization of DNA fragments from nuclei after chromatin decondensation obtained by high salt and disulfide-reducing agents treatment (Speit et al. 2009). TUNEL assay relies on the enzymatic addiction of labeled nucleotides to an end of a break. The enzyme terminal deoxynucleotidyl transferase (TdT) catalyzes a template-independent addition of deoxyribonucleoside triphosphates to the 3'-hydroxyl ends of double- or single-stranded DNA generates DNA strands with exposed 3'-hydroxyl ends. The amount of SSB- and DSBs is analyzed on single cells by FCM (Sakkas et al. 2002). SCSA detects the susceptibility of sperm chromatin to acid denaturation. In this technique, sperm are incubated in suspension with a mild acid solution under the hypothesis that only the fragmented DNA is denatured. Cells are stained with acridine orange, which emit a red fluorescence when bound to singlestranded DNA and a green fluorescence when intercalated into the double helix, and analyzed by FCM (Spano \& Evenson 1993). The comparisons of results obtained with the different techniques show a good correlation among the tests in revealing sperm with DNA strand breaks induced by DNAse I. Furthermore, the comparable results obtained with alkaline and neutral comet assay were in agreement with a prevalence of DSBs induced by DNAse I. The slope of linear regressions indicates that the same amount of damaged cells is revealed by methods detecting DNA strand breaks (alkaline and neutral comet assay and TUNEL assay). On the contrary, when comparing comet and TUNEL assays with SCSA, especially in the case of mouse sperm, only a small percentage of damaged sperm were also SCSA positive. It must be considered that SCSA does not directly measure DNA breaks but the susceptibility of sperm to acid-induced DNA denaturation. It is likely that the susceptibility to acidic denaturation does not rely only on the amount of DNA strand breaks but also on their relative position within the chromatin: it could be speculated that mouse chromatin has such a structure that its DNAse $\mathrm{I}$-accessible sites are distributed in a way that breaks do not produce enough chromatin relaxation to make DNA prone to acidic denaturation.

The need of a further validation and standardization of methods to assess sperm DNA integrity before their application in clinical, epidemiological, and toxicological research has been recently stressed (Barratt et al. 2010). In particular, reference control samples seem essential to estimate intra- and inter-laboratory variability and to understand the findings obtained with the different techniques. Our results suggest that DNAse I 
could be useful for evaluating and comparing the performance of different techniques in their capacity to pick up sperm DNA breaks. Furthermore, the different responses obtained in the tested species underline that species-specific differences in sperm chromatin structure should be considered when extrapolating results from experimental animal studies to human risk assessment, especially in the case of bulky molecules. Finally, as the histone to protamine ratio seems to be associated with fertility potential in humans (Carrell et al. 2007), further investigation could address the inter-individual sensitivity to DNAse I digestion in sperm from normal donors and infertile patients, and evaluate the predictive power of this feature for infertility diagnosis.

\section{Materials and Methods}

\section{Samples}

Human sperm was collected, after informed consent, from ten healthy, normospermic volunteers, pooled, aliquoted, and, without further manipulation, immediately frozen in cryotubes, and placed at $-80{ }^{\circ} \mathrm{C}$ (Spano et al. 2000). Bull sperm: cryopreserved aliquotes were purchased from Semenitaly (Modena, Italy) and maintained in liquid nitrogen. Mouse epididymal spermatozoa were sampled from 3-month-old C57/Bl6 mice. After killing, sperm collected from cauda epididymis were suspended in TNE buffer $(150 \mathrm{mM} \mathrm{NaCl}$, $10 \mathrm{mM}$ Tris- $\mathrm{HCl}, 1 \mathrm{mM} \mathrm{Na} \mathrm{E}_{2} \mathrm{EDTA}, \mathrm{pH}$ 7.4), centrifuged, resuspended in TNE buffer plus $10 \%$ glycerol, aliquoted, and frozen at $-80{ }^{\circ} \mathrm{C}$ (Cordelli et al. 2003). The experiments with mice were approved by the Institutional Animal Care and Use Committee and officially authorized by the National Ministry of Health.

\section{Treatment}

Semen samples were thawed at room temperature, washed in PBS, and treated as follows.

\section{DNAse I treatment}

Pellets were resuspended for $2 \mathrm{~min}$ in a permeabilizing solution $(0.1 \%$ sodium citrate, $0.1 \%$ Triton $\mathrm{X}-100)$ and treated for $30 \mathrm{~min}$ at $37^{\circ} \mathrm{C}$ with different concentrations of DNAse I $(2000 \mathrm{U} / \mathrm{mg}$, Roche Diagnostics) in PBS $+5 \mathrm{mM} \mathrm{MgCl}$. DNAse I concentrations were 0, 1, 2, 10, 100, and $1000 \mathrm{U} / \mathrm{ml}$.

\section{$\mathrm{H}_{2} \mathrm{O}_{2}$ treatment}

Samples were treated for $1 \mathrm{~h}$ at $37{ }^{\circ} \mathrm{C}$ with different concentrations of $\mathrm{H}_{2} \mathrm{O}_{2}$ (Sigma-Aldrich). $\mathrm{H}_{2} \mathrm{O}_{2}$ concentrations were 0 , $0.1,1,10$, and $100 \mathrm{mM}$ in PBS. At the end of the treatment, samples were washed in PBS and analyzed by the different techniques.

\section{Comet assay}

Four slides were prepared from each sample, two for the alkaline comet assay $(\mathrm{pH} \mathrm{12.1)}$ and the other for the neutral comet assay ( $\mathrm{pH}$ 8.0). The assay was performed essentially according to Cordelli et al. (2003). The slides were immersed in a lysing solution $\left(2.5 \mathrm{M} \mathrm{NaCl}, 100 \mathrm{mM} \mathrm{Na}{ }_{2}\right.$ EDTA, $10 \mathrm{mM}$ Tris, $\mathrm{pH} 10$ ) containing $10 \%$ DMSO (Carlo Erba, Milan, Italy) and $1 \%$ Triton X-100 (Sigma), overnight at $4{ }^{\circ} \mathrm{C}$. Slides were then immersed $30 \mathrm{~min}$ in $10 \mathrm{mM}$ dithiothreitol (Sigma) in lysis solution. Slides were placed in a horizontal gel electrophoresis tank (Starlab, Milan, Italy) with fresh electrophoresis buffer. Conditions for alkaline comet assay were as follows: DNA denaturation: $10 \mathrm{~min}$ at $4{ }^{\circ} \mathrm{C}$ in alkaline electrophoresis buffer (300 mM NaOH, $1 \mathrm{mM} \mathrm{Na} 2$ EDTA; $\mathrm{HCl}$ was added to reach $\mathrm{pH}$ 12.1). Electrophoresis: $5 \mathrm{~min}, 27 \mathrm{~V}(0.8 \mathrm{~V} / \mathrm{cm}), 300 \mathrm{~mA}$ at $4{ }^{\circ} \mathrm{C}$. Conditions for neutral comet assay were: equilibration: $20 \mathrm{~min}$ in TBE buffer ( $2 \mathrm{mM} \mathrm{Na}_{2}$ EDTA, $90 \mathrm{mM}$ Tris, and $90 \mathrm{mM}$ boric acid; $\mathrm{pH}$ 8) at $4{ }^{\circ} \mathrm{C}$. Electrophoresis: $5 \mathrm{~min}, 27 \mathrm{~V}(0.8 \mathrm{~V} / \mathrm{cm})$, $10 \mathrm{~mA}$ at $4{ }^{\circ} \mathrm{C}$.

After electrophoresis, the slides were immersed in $0.3 \mathrm{M}$ sodium acetate in ethanol for $30 \mathrm{~min}$. Microgels were then dehydrated in absolute ethanol for $2 \mathrm{~h}$ and immersed for $5 \mathrm{~min}$ in $70 \%$ ethanol. Slides were air-dried at room temperature. Immediately before scoring, slides were stained with $12 \mu \mathrm{g} / \mathrm{ml}$ ethidium bromide (Sigma) and examined, at $200 \times$ magnification, with an Olympus fluorescent microscope. Slides were analyzed by a computerized image analysis system (Delta Sistemi, Rome, Italy). To evaluate the amount of DNA damage, 100 cells were analysed from two different slides, and computergenerated fraction of tail DNA values were used. To quantify the percentage of sperm with abnormal DNA, a cutoff of $10 \%$ tail DNA was used to discriminate undamaged and damaged cells.

\section{Flow cytometric SCSA}

Sperm cells were prepared and stained according to the procedure described in Spano et al. (2005). Briefly, aliquots $(0.2 \mathrm{ml})$ containing $(1-2) \times 10^{6}$ cells were mixed with $0.4 \mathrm{ml}$ acid-detergent solution $(0.1 \%$ Triton $\mathrm{X}-100,0.15 \mathrm{M} \mathrm{NaCl}$, and $0.08 \mathrm{M} \mathrm{HCl}, \mathrm{pH} 1.2)$. After $30 \mathrm{~s}$, the cells were stained by adding $1.2 \mathrm{ml}$ of a solution containing $6 \mu \mathrm{g} / \mathrm{ml}$ of chromatographically purified acridine orange (AO; Molecular Probes, Eugene, OR, USA) in staining buffer $(0.1 \mathrm{M}$ citric acid, $0.2 \mathrm{M}$ $\mathrm{Na}_{2} \mathrm{HPO}_{4}, 1 \mathrm{mM}$ EDTA, $0.15 \mathrm{M} \mathrm{NaCl}, \mathrm{pH}$ 6.0). When excited with blue light, $\mathrm{AO}$ intercalated into double-stranded DNA fluoresces green. AO associated with single-stranded nucleic acids emits red fluorescence. Sperm abnormal chromatin structure, here defined as an increased susceptibility to induced denaturation, is FCM measured, on cell-by-cell basis, in terms of green (native DNA) to red (denatured, single-stranded DNA) shift. AO fluorescence intensity shift is described using the index called DNA fragmentation index (DFI) representing the ratio of red to total (red+green) fluorescence. Normal, native chromatin remains structurally sound and produces a narrow DFI distribution. DNA in sperm with abnormal chromatin structure has increased red fluorescence, which yields an altered DFI distribution. Cells were analysed by BD FACSCalibur flow cytometer (Becton Dickinson, San Josè, CA, USA). Green fluorescence was collected after a $530 \pm 30 \mathrm{~nm}$ band pass filter and red fluorescence after a LP620 long pass filter. The two colors were splitted by a $560 \mathrm{~nm}$ dichroic filter. Data were stored in list-mode at 10-bit 
resolution. A total of $1 \times 10^{4}$ events were accumulated for each measurement. For uniformity, recorded measurements were begun $3 \mathrm{~min}$ after staining. Measurement rate was about 200 cells/s. Cytogram and DFI analyses were carried out on the list-mode data by using the SCSASoft software (SCSA Diagnostics, Brooking, SD, USA).

\section{Flow cytometric in situ nick end labeling (TUNEL) assay}

TUNEL labeling was carried out using the In Situ Cell Death Detection Kit Fluorescein (Roche Diagnostics) and was performed according to the manufacturer's instructions. Briefly, samples were centrifuged ( $500 \mathrm{~g}$ for $6 \mathrm{~min}$ ), and the pellet was resuspended in $\mathrm{PBS}$ with $1 \%(\mathrm{w} / \mathrm{v}) \mathrm{BSA}(\mathrm{pH} 7.4)$ to a final concentration of $1.5 \times 10^{6}$ cells $/ 100 \mu$ l. One hundred microlitres of $1 \%$ paraformaldehyde was added, and samples were shaken for $1 \mathrm{~h}$ at $15-25{ }^{\circ} \mathrm{C}$. After fixation, the cells were washed once, resuspended in $1 \mathrm{ml} \mathrm{PBS} / 1 \% \mathrm{BSA}$, and divided into two aliquots (negative control and test sample). After centrifugation, test samples were resuspended in $50-\mu \mathrm{l}$ reaction mix containing 45- $\mu$ l labeling solution (supplied with the in situ Cell Death Detection Kit) and 5- $\mu$ I TdT. The negative controls were suspended in the labeling solution without TdT. Samples were incubated for $1 \mathrm{~h}$ at $37^{\circ} \mathrm{C}$ in the darkness. At the end of incubation, cells were washed twice and resuspended in PBS containing $5 \mu \mathrm{g} / \mathrm{ml}$ propidium iodide. Cells were analysed by BD FACSCalibur flow cytometer (Becton Dickinson). Green fluorescence was collected after a $530 \pm 30 \mathrm{~nm}$ band pass filter and red fluorescence after a LP620 long pass filter. A total of $1 \times 10^{4}$ events were accumulated for each measurement. A marker was set in the TUNEL dot plot at the borderline of background signals, as determined from the negative sample; the same marker was maintained in all plots to quantify the percentage of positive cells.

\section{Statistical analysis}

Statistical analysis was performed using SPSS software (SPSS, Inc., Chicago, IL, USA). Comparison between group means was performed by one-way ANOVA, and Dunnett's test was used for post-hoc comparison of treatments to controls. Comparison between the percentages of damaged cells observed with the different techniques was performed by two-tailed Pearson's correlation. For all experiments, a $P$ value of $<0.05$ was considered significant.

\section{Declaration of interest}

The authors declare that there is no conflict of interest that could be perceived as prejudicing the impartiality of the research reported.

\section{Funding}

This work has been partially supported by the EU-Project 'Development of a novel approach in hazard and risk assessment or reproductive toxicity by a combination and application of in vitro, tissue and sensor technologies' ReProTect (LSHB-CT-2004-503257).

\section{References}

Aitken RJ \& De Iuliis GN 2010 On the possible origins of DNA damage in human spermatozoa. Molecular Human Reproduction 16 3-13. (doi:10.1093/molehr/gap059)

Aitken RJ, De Iuliis GN \& McLachlan RI 2009 Biological and clinical significance of DNA damage in the male germ line. International Journal of Andrology 32 46-56. (doi:10.1111/j.1365-2605.2008. 00943.x)

Aoki VW, Moskovtsev SI, Willis J, Liu L, Mullen JB \& Carrell DT 2005a DNA integrity is compromised in protamine-deficient human sperm. Journal of Andrology 26 741-748. (doi:10.2164/ jandrol.05063)

Aoki VW, Liu L \& Carrell DT 2005b Identification and evaluation of a novel sperm protamine abnormality in a population of infertile males. Human Reproduction 20 1298-1306. (doi:10.1093/humrep/ deh798)

Arpanahi A, Brinkworth M, Iles D, Krawetz SA, Paradowska A, Platts AE, Saida M, Steger K, Tedder P \& Miller D 2009 Endonuclease-sensitive regions of human spermatozoal chromatin are highly enriched in promoter and CTCF binding sequences. Genome Research 19 1338-1349. (doi:10.1101/gr.094953.109)

Barratt CL, Aitken RJ, Bjorndahl L, Carrell DT, de Boer P, Kvist U, Lewis SE, Perreault SD, Perry MJ, Ramos L et al. 2010 Sperm DNA: organization, protection and vulnerability: from basic science to clinical applications - a position report. Human Reproduction $\mathbf{2 5}$ 824-838. (doi:10.1093/humrep/dep465)

Barroso G, Valdespin C, Vega E, Kershenovich R, Avila R, Avendano C \& Oehninger S 2009 Developmental sperm contributions: fertilization and beyond. Fertility and Sterility 92 835-848. (doi:10.1016/ j.fertnstert.2009.06.030)

Bench GS, Friz AM, Corzett MH, Morse DH \& Balhorn R 1996 DNA and total protamine massess in individual sperm from fertile mammalian subjects. Cytometry 23 263-271. (doi:10.1002/ (SICl)1097-0320(19960401)23:4<263::AID-CYTO1>3.0.CO;2-I)

Bennetts LE \& Aitken RJ 2005 A comparative study of oxidative DNA damage in mammalian spermatozoa. Molecular Reproduction and Development 71 77-87. (doi:10.1002/mrd.20285)

Bennetts LE, De luliis GN, Nixon B, Kime M, Zelski K, McVicar CM, Lewis SE \& Aitken RJ 2008 Impact of estrogenic compounds on DNA integrity in human spermatozoa: evidence for cross-linking and redox cycling activities. Mutation Research 641 1-11. (doi:10.1016/ j.mrfmmm.2008.02.002)

Braun RE 2001 Packaging paternal chromosomes with protamine. Nature Genetics 28 10-12. (doi:10.1038/88194)

Bungum M, Humaidan P, Axmon A, Spano M, Bungum L, Erenpreiss J \& Giwercman A 2007 Sperm DNA integrity assessment in prediction of assisted reproduction technology outcome. Human Reproduction 22 174-179. (doi:10.1093/humrep/del326)

Carrell DT, Emery BR \& Hammoud S 2007 Altered protamine expression and diminished spermatogenesis: what is the link? Human Reproduction Update 13 313-327. (doi:10.1093/humupd/ dml057)

Chohan KR, Griffin JT, Lafromboise M, De Jonge CJ \& Carrell DT 2006 Comparison of chromatin assays for DNA fragmentation evaluation in human sperm. Journal of Andrology 27 53-59. (doi:10.2164/jandrol. 05068)

Collins AR, Oscoz AA, Brunborg G, Gaivao I, Giovannelli L, Kruszewski M, Smith CC \& Stetina R 2008 The comet assay: topical issues. Mutagenesis 23 143-151. (doi:10.1093/mutage/gem051)

Cordelli E, Fresegna AM, Leter G, Eleuteri P, Spano M \& Villani P 2003 Evaluation of DNA damage in different stages of mouse spermatogenesis after testicular X irradiation. Radiation Research $\mathbf{1 6 0}$ 443-451. (doi:10.1667/RR3053)

Corzett M, Mazrimas J \& Balhorn R 2002 Protamine 1: protamine 2 stoichiometry in the sperm of eutherian mammals. Molecular Reproduction and Development 61 519-527. (doi:10.1002/mrd. 10105)

Dadoune JP 2003 Expression of mammalian spermatozoal nucleoproteins. Microscopy Research and Technique 61 56-75. (doi:10.1002/ jemt.10317) 
Delbès G, Hales BF \& Robaire B 2010 Toxicants and human sperm chromatin integrity. Molecular Human Reproduction 16 14-22. (doi:10.1093/molehr/gap087)

Evenson DP \& Wixon R 2005 Environmental toxicants cause sperm DNA fragmentation as detected by the sperm chromatin structure assay (SCSA). Toxicology and Applied Pharmacology 207 (2 Supplement) 532-537. (doi:10.1016/j.taap.2005.03.021)

Evenson DP, Darzynkiewicz Z \& Melamed MR 1980 Relation of mammalian sperm chromatin heterogeneity to fertility. Science $\mathbf{2 1 0}$ 1131-1133. (doi:10.1126/science.7444440)

Evenson DP, Larson KL \& Jost LK 2002 Sperm chromatin structure assay: its clinical use for detecting sperm DNA fragmentation in male infertility and comparisons with other techniques. Journal of Andrology 23 25-43.

Gorczyca W, Traganos F, Jesionowska H \& Darzynkiewicz Z 1993 Presence of DNA strand breaks and increased sensitivity of DNA in situ to denaturation in abnormal human sperm cells: analogy to apoptosis of somatic cells. Experimental Cell Research 207 202-205. (doi:10.1006/excr.1993.1182)

Hammoud SS, Nix DA, Zhang H, Purwar J, Carrell DT \& Cairns BR 2009 Distinctive chromatin in human sperm packages genes for embryo development. Nature 460 473-478. (doi:10.1038/ nature08162)

Hughes CM, Lewis SEM, McKelvey-Martin VJ \& Thompson W 1996 A comparison of baseline and induced DNA damage in human spermatozoa from fertile and infertile men using a modified comet assay. Molecular Human Reproduction 2 613-619. (doi:10.1093/ molehr/2.8.613)

Lewis SE \& Agbaje IM 2008 Using the alkaline comet assay in prognostic tests for male infertility and assisted reproductive technology outcomes. Mutagenesis 23 163-170. (doi:10.1093/ mutage/gem052)

Miller D, Brinkworth M \& Iles D 2010 Paternal DNA packaging in spermatozoa: more than the sum of its parts? DNA, histones, protamines and epigenetics Reproduction 139 287-301. (doi:10. 1530/REP-09-0281)

Mitchell LA, De Iuliis GN \& Aitken RJ 2010 The TUNEL assay consistently underestimates DNA damage in human spermatozoa and is influenced by DNA compaction and cell vitality: development of an improved methodology. International Journal of Andrology [in press]. (doi:10.1111/j.1365-2605.2009.01042.x)

Nazarov IB, Shlyakhtenko LS, Lyubchenko YL, Zalenskaya IA \& Zalensky AO 2008 Sperm chromatin released by nucleases. Systems Biology in Reproductive Medicine 54 37-46. (doi:10.1080/ 19396360701876849)

Oliva R 2006 Protamines and male infertility. Human Reproduction Update 12 417-435. (doi:10.1093/humupd/dml009)

Palmer DK, O'Day K, Le Trong H, Charbonneau H \& Margolis RL 1991 Purification of the centromere-specific protein CENP-A and demonstration that it is a distinctive histone. PNAS 88 3734-3738. (doi:10.1073/pnas.88.9.3734)

Pan CQ \& Lazarus RA 1997 Engineering hyperactive variants of human deoxyribonuclease I by altering its functional properties. Biochemistry 36 6624-6632. (doi:10.1021/bi962960x)

Perry MJ 2008 Effects of environmental and occupational pesticide exposure on human sperm: a systematic review. Human Reproduction Update 14 233-242. (doi:10.1093/humupd/dmm039)

Pittoggi C, Renzi L, Zaccagnini G, Cimini D, Degrassi F, Giordano R, Magnano AR, Lorenzini R, Lavia P \& Spadafora C 1999 A fraction of mouse sperm chromatin is organized in nucleosomal hypersensitive domains enriched in retroposon DNA. Journal of Cell Science 112 3537-3548.

Rignell-Hydbom A, Rylander L, Giwercman A, Jonsson BA, Lindh C, Eleuteri P, Rescia M, Leter G, Cordelli E, Spano M et al. 2005 Exposure to $\mathrm{PCBs}$ and $p, p^{\prime}-\mathrm{DDE}$ and human sperm chromatin integrity. Environmental Health Perspectives 113 175-179. (doi:10. 1289/ehp.7252)
Rueff J, Bras A, Cristovao L, Mexia J, Sa da Costa M \& Pires V 1993 DNA strand breaks and chromosomal aberrations induced by $\mathrm{H}_{2} \mathrm{O}_{2}$ and 60Co gamma-radiation. Mutation Research 289 197-204. (doi:10.1016/0027-5107(93)90070-V)

Rybar R, Kopecka V, Prinosilova P, Kubickova S, Veznik Z \& Rubes J 2009 Fertile bull sperm aneuploidy and chromatin integrity in relationship to fertility. International Journal of Andrology 33 613-622. (doi:10.1111/j.1365-2605.2009.00989.x)

Sakkas D \& Alvarez JG 2010 Sperm DNA fragmentation: mechanisms of origin, impact on reproductive outcome, and analysis. Fertility and Sterility 93 1027-1036. (doi:10.1016/j.fertnstert.2009.10.046)

Sakkas D, Moffatt O, Manicardi GC, Mariethoz E, Tarozzi N \& Bizzaro D 2002 Nature of DNA damage in ejaculated human spermatozoa and the possible involvement of apoptosis. Biology of Reproduction 66 1061-1067. (doi:10.1095/biolreprod66.4.1061)

Singh NP, Danner DB, Tice RR, McCoy MT, Collins GD \& Schneider EL 1989 Abundant alkali-sensitive sites in DNA of human and mouse sperm. Experimental Cell Research 184 461-470. (doi:10.1016/ 0014-4827(89)90344-3)

Sotolongo B, Lino E \& Ward WS 2003 Ability of hamster spermatozoa to digest their own DNA. Biology of Reproduction 69 2029-2035. (doi:10.1095/biolreprod.103.020594)

Sotolongo B, Huang TT, Isenberger E \& Ward WS 2005 An endogenous nuclease in hamster, mouse, and human spermatozoa cleaves DNA into loop-sized fragments. Journal of Andrology 26 272-280.

Spano M \& Evenson DP 1993 Flow cytometric analysis for reproductive biology. Biology of the Cell 78 53-62. (doi:10.1016/0248-4900 (93)90114-T)

Spano M, Bonde JP, Hjøllund HI, Kolstad HA, Cordelli E \& Leter G 2000 Sperm chromatin damage impairs human fertility. The Danish First Pregnancy Planner Study Team. Fertility and Sterility 73 43-50. (doi:10.1016/S0015-0282(99)00462-8)

Spano M, Toft G, Hagmar L, Eleuteri P, Rescia M, Rignell-Hydbom A, Tyrkiel E, Zvyezday V \& Bonde JP 2005 Exposure to PCB and $p, p^{\prime}-\mathrm{DDE}$ in European and Inuit populations: impact on human sperm chromatin integrity. Human Reproduction 20 3488-3499. (doi:10.1093/humrep/dei297)

Speit G, Vasquez M \& Hartmann A 2009 The comet assay as an indicator test for germ cell genotoxicity. Mutation Research $\mathbf{6 8 1}$ 3-12. (doi:10.1016/j.mrrev.2008.03.005)

Staynov DZ 2000 DNase I digestion reveals alternating asymmetrical protection of the nucleosome by the higher order chromatin structure. Nucleic Acids Research 28 3092-3099. (doi:10.1093/ nar/28.16.3092)

Staynov DZ 2008 DNase I footprinting of the nucleosome in whole nuclei. Biochemical and Biophysical Research Communications 372 226-229. (doi:10.1016/j.bbrc.2008.05.024)

Traina ME, Rescia M, Urbani E, Mantovani A, Macri C, Ricciardi C, Stazi AV, Fazzi P, Cordelli E, Eleuteri P et al. 2003 Long-lasting effects of lindane on mouse spermatogenesis induced by in utero exposure. Reproductive Toxicology 17 25-35. (doi:10.1016/S08906238(02)00101-6)

Ward WS 2010 Function of sperm chromatin structural elements in fertilization and development. Molecular Human Reproduction 16 30-36. (doi:10.1093/molehr/gap080)

Wykes SM \& Krawetz SA 2003 The structural organization of sperm chromatin. Journal of Biological Chemistry 278 29471-29477. (doi:10.1074/jbc.M304545200)

Zalenskaya IA, Bradbury EM \& Zalensky AO 2000 Chromatin structure of telomere domain in human sperm. Biochemical and Biophysical Research Communications 279 213-218. (doi:10.1006/ bbrc.2000.3917)

Received 7 April 2010

First decision 6 May 2010

Accepted 28 July 2010 